\title{
GRANULOMA PIOGENIK MULTIPEL
}

\author{
Tracy O. H. Lawalata \\ Aris A. Tjahjadi \\ Elly E. Ch. Oroh \\ Pieter L. Suling
}

\author{
Bagian Ilmu Kesehatan Kulit dan Kelamin RSUP Prof. Dr. R. D. Kandou \\ Fakultas Kedokteran Universitas Sam Ratulangi Manado \\ Email: lawalata_tracy@yahoo.com
}

\begin{abstract}
Pyogenic granuloma is a benign proliferating vascular tumor of the skin and mucous membrane that follows a minor injury or infection. This tumor occurs mostly in children or young adults and can be detected as a bright red solitary papule or nodule with a diameter of 5$10 \mathrm{~mm}$ that grows rapidly within 1-3 weeks. The papule or nodule is often covered by a subtle collaret of scales, brittle, and easily bleeding even with minor trauma. Methods of treatment are excision, electro surgery, cryosurgery, laser, or combinations thereof, and imiquimod cream. We reported a case of a 27-year-old male who had suffered from six reddish papules on the back of his left ear for six months. It began with one milliar tumor in size then there arose five other tumors around it, rapidly growing, which easily bled within several weeks. Skin lesions were multiple pedunculated erythematous papules, tender, and $0.2-0.5 \mathrm{~cm}$ in diameter. Histopathological features demonstrated a pyogenic granuloma. The treatment which performed a shave excision followed by electro surgery had a satisfactory outcome.
\end{abstract}

Keywords: multiple pyogenic granuloma, shave excision

\begin{abstract}
Abstrak : Granuloma piogenik merupakan tumor vaskuler proliferatif jinak pada kulit dan membran mukosa yang sering mengikuti suatu trauma minor atau infeksi. Tumor ini lebih sering terjadi pada anak dan dewasa muda. Lesi berupa papul atau nodul soliter berwarna merah terang dengan ukuran 5-10 mm, tumbuh cepat dalam 1-3 minggu namun rapuh, seringkali dengan koleret skuama halus dan mudah berdarah dengan trauma ringan. Terapi dapat berupa bedah eksisi, bedah listrik, bedah beku, laser atau kombinasi diantaranya, dan krim imiquimod. Kami melaporkan satu kasus granuloma piogenik multipel dan penatalaksanaannya pada seorang laki-laki berusia 27 tahun dengan enam benjolan berwarna merah pada bagian belakang telinga kiri sejak enam bulan yang lalu. Awalnya hanya berupa satu benjolan sebesar kepala jarum pentul, kemudian setelah beberapa minggu timbul lima benjolan lain disekitarnya yang cepat membesar, serta mudah berdarah. Kelainan kulit berupa papula eritem, multipel, bertangkai, teraba kenyal, dan berdiameter $0,2-0,5 \mathrm{~cm}$. Gambaran histopatologik menunjukkan suatu granuloma piogenik. Penatalaksanaan yang dilakukan dengan shave excision diikuti bedah listrik memberikan hasil yang memuaskan.
\end{abstract}

Kata kunci: granuloma piogenik multipel, shave excision

Granuloma piogenik merupakan tumor vaskuler proliferatif jinak pada kulit dan membran mukosa yang sering mengikuti suatu trauma minor dan infeksi. ${ }^{1}$

Granuloma piogenik dapat terjadi pada semua umur dan merupakan salah satu dari tumor-tumor vaskuler yang paling sering ditemukan pada bayi dan anak-anak. Juga dapat terjadi pada orang dewasa, terutama pada wanita hamil. ${ }^{2}$ Tidak terdapat perbedaan bermakna antara insidens pada pria dan wanita. ${ }^{3}$ Walaupun demikian penelitian lain 
melaporkan bahwa tumor ini lebih sering pada wanita oleh karena fenomena tumor pada wanita hamil. ${ }^{4}$ Selain itu tumor ini dapat terjadi pada semua ras. ${ }^{3}$ Tumor ini sering timbul soliter tetapi bisa terjadi lesi-lesi satelit yang multipel. ${ }^{5}$

Sampai sekarang penyebab granuloma piogenik belum diketahui secara pasti, namun biasanya timbul setelah terjadi trauma minor. ${ }^{3,5,6}$ Kemungkinan faktor predisposisi lainnya meliputi iritasi kronis, peningkatan hormon seks wanita, infeksi, virus onkogenik dan anastomosis arteriovenosa. ${ }^{4,5}$

Gambaran klinis granuloma piogenik berupa papul atau nodul soliter berwarna merah terang dengan diameter 5-10 $\mathrm{mm}$, tumbuh cepat dalam 1-3 minggu, namun rapuh dan mudah berdarah dengan trauma ringan, serta terdapat koleret dan skuama halus disekitarnya,. Lesi sering berulang dan lesi yang rekuren dapat memiliki satu atau beberapa lesi satelit lainnya. ${ }^{2,3,5}$

Diagnosis granuloma piogenik dapat ditegakkan tanpa memerlukan pemeriksaan laboratorium. ${ }^{3,7}$ Pada pemeriksaan histopatologik tampak gambaran proliferasi pembuluh-pembuluh darah kecil yang menerobos epidermis dan membentuk tumor globular yang bertangkai. ${ }^{1,6}$ Diagnosis banding granuloma piogenik adalah angiomatosis basiler dan sarkoma Kaposi. ${ }^{3,4,6}$

Penatalaksanaan granuloma piogenik dapat berupa bedah eksisi, bedah listrik, bedah beku, laser, atau kombinasi diantaranya, ${ }^{3,4,8}$ dan aplikasi krim imiquimod. ${ }^{9-11}$

Granuloma piogenik mempunyai kecenderungan untuk timbul kembali dan rekurensinya dapat mencapai $40-50 \%{ }^{4}$

Berikut ini akan dilaporkan satu kasus granuloma piogenik multipel di bagian belakang telinga kiri pada seorang laki-laki dewasa dengan riwayat kebiasaan menggaruk telinga.

\section{LAPORAN KASUS}

Seorang laki-laki berusia 27 tahun, bangsa Indonesia, suku Toraja, beragama Kristen Protestan, status belum menikah, pekerjaan sebagai sales promotion, datang ke poliklinik Kulit dan Kelamin RSU Prof. Dr. R.D.
Kandou Manado tanggal 26 September 2006 dengan keluhan utama terdapat enam benjolan kemerahan di bagian belakang telinga kiri sejak enam bulan yang lalu.

Dari hasil anamnesis pasien didapatkan awalnya hanya berupa satu benjolan yang berukuran kecil seperti kepala jarum pentul, tidak gatal dan tidak nyeri. Dalam beberapa minggu benjolan bertambah banyak dan membesar seperti biji jagung. Ia sudah pernah mencoba menghilangkan benjolan tersebut dengan cara menggaruk tetapi tidak berhasil. Selanjutnya ia berobat ke dokter praktik dan diberikan obat minum maupun oles. Benjolan-benjolan tersebut hanya mengecil untuk beberapa hari tetapi kemudian membesar kembali. Pasien datang kontrol kembali dan diberi obat yang diteteskan ke benjolan-benjolan tersebut dimana terasa nyeri. Hasilnya terdapat sedikit perbaikan, namun beberapa hari kemudian keluhan berulang kembali. Pasien baru pertama kali mengalami kelainan ini. Riwayat kebiasaan adalah ia sering menggaruk telinga terutama saat merasa melakukan kesalahan atau merasa canggung. Tidak didapatkan adanya riwayat penggunaan obat-obatan golongan retinoid sebelumnya, riwayat alergi makanan dan obat-obatan, maupun penyakit sistemik lainnya.

Pemeriksaan fisik didapatkan pasien tampak sakit ringan dengan gizi baik. Status generalisnya dalam batas normal. Status dermatologis pada bagian posterior regio aurikularis sinistra terdapat papula eritem, multipel, berukuran diameter $0,2-0,5 \mathrm{~cm}$, bertangkai, permukaan licin, teraba kenyal dan mudah berdarah (Gambar 1).

Hasil pemeriksaan laboratorium darah diperoleh HB 13,5 gr/dL, lekosit $9.800 / \mathrm{mm}^{3}$, trombosit $350.000 / \mathrm{mm}^{3}$, masa perdarahan satu menit, dan masa pembekuan 10 menit.

Hasil pemeriksaan histopatologik biopsi eksisi tampak jaringan diliputi oleh epidermis, tampak jaringan ikat longgar dengan proliferasi kapiler dan banyak infiltrasi selsel radang limfosit, tetapi tidak tampak tanda keganasan; hal ini menunjukkan gambaran granuloma piogenik.

Pasien didiagnosis sebagai granuloma piogenik multipel, dengan diagnosis banding 
angiomatosis basiler dan sarkoma Kaposi.

Penanganan yang dilakukan pada pasien ini adalah shave exision (eksisi sayatan dengan silet) diikuti dengan elektrokauterisasi. Kemudian jaringan hasil eksisi dilakukan pemeriksaan histopatologik. Untuk pengobatan medikamentosa diberikan siprofloksasin $2 \mathrm{x}$ $500 \mathrm{mg}$ selama lima hari dan salep asam fusidat tiga kali pemberian dalam sehari.

Prognosis pada pasien ini adalah baik, walaupun terdapat kemungkinan terjadi ke- kambuhan.

Pada pemeriksaan lanjutan tanggal 9 Oktober 2006, lesi lama mengalami perbaikan ditandai dengan terbentuknya krusta dan lesi yang tidak mudah berdarah. Tidak terdapat benjolan lain pada bekas benjolan dan sekitarnya (Gambar 2). Diagnosis akhir adalah granuloma piogenik multipel, dan pasien dianjurkan untuk kontrol kembali, terutama bila timbul benjolan yang sama di daerah tersebut.

Gambar 1. Kunjungan pertama tanggal 26 September 2006
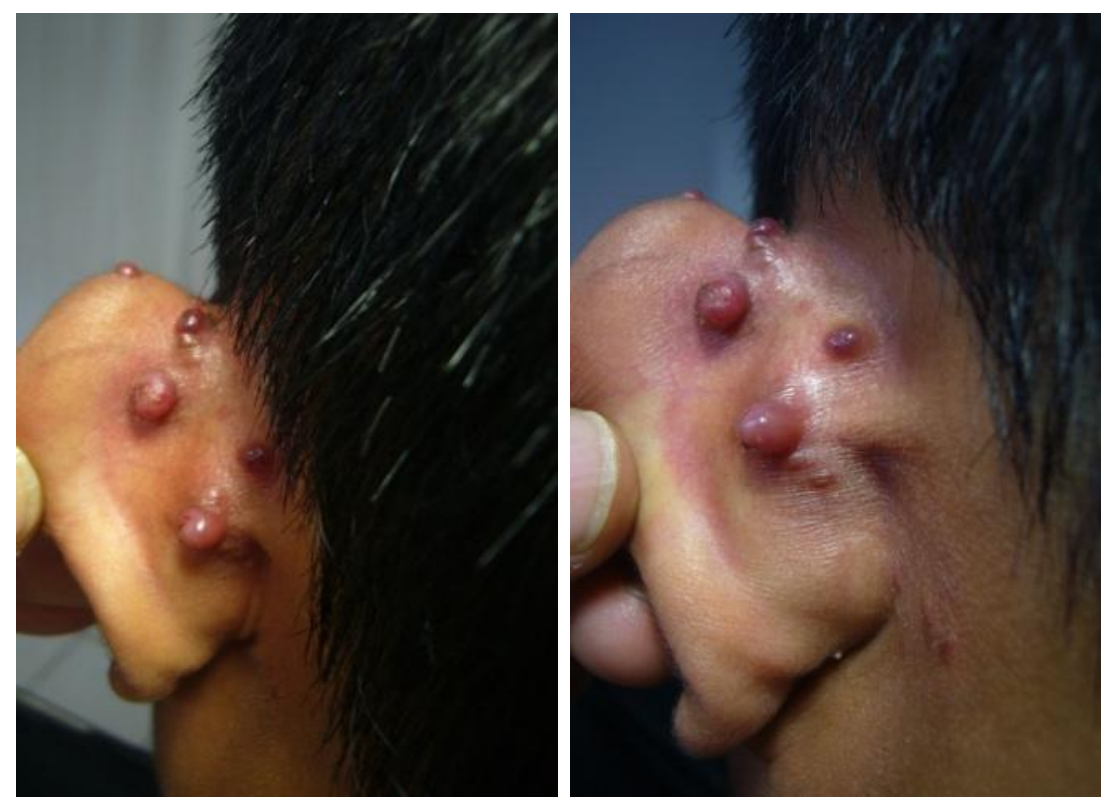

Gambar 2. Kunjungan kedua tanggal 9 Oktober 2006
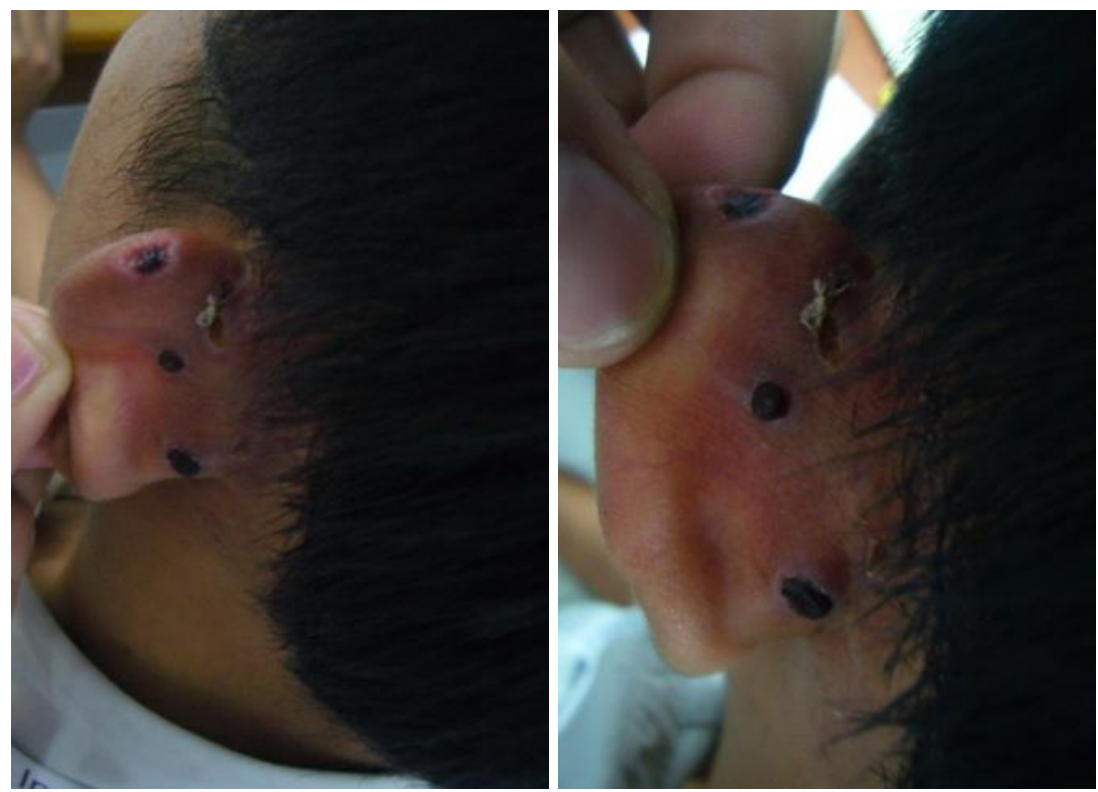


\section{PEMBAHASAN}

Granuloma piogenik merupakan salah satu tumor vaskular proliferatif jinak yang didapat. Jenis ini timbul pada kulit dan membran mukosa berupa papul atau nodul berwarna merah terang dengan ukuran 5-10 $\mathrm{mm}$, sering soliter, tumbuh cepat namun rapuh dan mudah berdarah, serta didahului oleh adanya trauma minor atau infeksi. ${ }^{1-3,5}$

Diagnosis granuloma piogenik multipel pada pasien ini ditegakkan berdasarkan anamnesis, pemeriksaan fisik dan pemeriksaan histopatologik.

Granuloma piogenik sering terjadi pada anak-anak dan dewasa muda terutama pada wanita hamil, ${ }^{2,4,5}$ namun jarang terjadi pada anak dibawah usia 6 bulan. ${ }^{1}$ Tidak terdapat perbedaan angka kejadian berda-sarkan jenis kelamin dan ras. ${ }^{3}$ Kasus ini adalah seorang laki-laki dewasa berusia 27 tahun dari suku Toraja.

Penyebab pasti granuloma piogenik belum diketahui, namun trauma dan obatobatan tertentu dapat merupakan faktor pencetus. ${ }^{2,3,5,10}$ Pada kasus ini, terjadinya granuloma piogenik diduga disebabkan karena adanya trauma minor berupa kebiasaan menggaruk telinga dengan kuku jari tangan saat pasien merasa bersalah ataupun canggung, dan terjadinya infeksi yang mengikuti trauma minor akibat garukan.

Secara klinis granuloma piogenik berupa papul atau nodul yang umumnya soliter, berwarna merah terang dengan ukuran diameter 5-10 mm, sedikit bertangkai atau tidak bertangkai, serta rapuh dan mudah berdarah dengan trauma ringan. Lokasi lesi biasanya terjadi pada daerah yang sering mengalami trauma, seperti pipi, dahi, jari, lengan bawah, leher, dan kadang-kadang permukaan mukosa mulut pada wanita hamil (granuloma gravidarum), namun bisa juga timbul pada bagian tubuh yang lain. ${ }^{2,3,5,6}$ Tes kompresi yang dilakukan pada granuloma piogenik memperlihatkan adanya perubahan warna yang terjadi secara parsial. ${ }^{3}$ Berdasarkan pemeriksaan fisik pada pasien, ditemukan adanya papul eritem sebanyak enam buah pada bagian posterior regio aurikularis sinistra dengan ukuran diameter $0,2-0,5 \mathrm{~cm}$, bertang- kai, permukaan licin, konsistensi kenyal, dan mudah berdarah. Tes kompresi yang dilakukan memperlihatkan adanya perubahan warna menjadi putih secara parsial.

Gambaran histopatologik granuloma piogenik bervariasi dan kadang-kadang tidak spesifik. Hal ini dipengaruhi oleh bagian lesi yang diambil, stadium atau lamanya lesi timbul, dan pengobatan yang telah dilakukan. ${ }^{3}$ Gambarannya memperlihatkan adanya proliferasi dari pembuluh-pembuluh darah kecil yang menerobos epidermis dan membentuk tumor globuler yang bertangkai. Epidermis membentuk sebuah koleret pada dasar lesi dan menutupi sebagian atau keseluruhan tumor dalam sebuah lapisan yang tipis. Sel-sel endotelial menjadi sedikit seperti pada jaringan granulasi baru dan dikelilingi oleh suatu populasi sel campuran dari fibroblas, sel mast, limfosit dan sel plasma dimana permukaannya mengalami erosi. ${ }^{2,3,8} \mathrm{Hal}$ ini sesuai dengan pemeriksaan histopatologik pada pasien dimana jaringan diliputi oleh epidermis dan tampak jaringan ikat longgar dengan proliferasi kapiler dan banyak infiltrasi sel-sel radang limfosit. Tidak tampak tanda ganas.

Diagnosis banding granuloma piogenik adalah angiomatosis basiler, yaitu penyakit proliferasi vaskuler infeksius yang disebabkan oleh Bartonella henselae (termasuk dalam famili Bartonellaceae) yang merupakan bakteri gram negatif dan sering terdapat pada pasien-pasien dengan HIV. Secara klinis dan histopatologik lesi-lesi angiomatosis basiler terlihat hampir sama dengan granuloma piogenik, namun berbeda dalam etiologis maupun patogenesisnya. Perjalanan penyakitnya terbagi menjadi dua bagian, yaitu infeksi lokal dan sistemik. Perbedaan yang paling utama dengan granuloma piogenik adalah lesinya terasa nyeri dan jika terjadi penyebaran infeksi sistemik akan disertai dengan demam, malaise, penurunan berat badan, mual, muntah, diare dan menggigil. ${ }^{1,3}$ Berdasarkan gambaran klinis diatas maka diagnosis banding dengan angiomatosis basiler dapat disingkirkan.

Diagnosis banding lainnya adalah sarkoma Kaposi yang merupakan neoplasia vaskuler multisistem, ditandai oleh adanya 
lesi mukokutan berwarna keunguan dan disertai edema disekitar organ terdekat yang terkena. Pada beberapa pasien, penyakit ini berhubungan dengan kondisi imunokompromais misalnya pada pasien HIV. Gambaran klinis diawali oleh makula berbentuk seperti ekimosis yang berubah menjadi papul, plak, nodul dan tumor berwarna merah keunguan, merah, merah muda dan coklat keunguan. Lesi awalnya timbul pada tempat yang mengalami trauma dan biasanya pada daerah akral. ${ }^{2,3}$ Berdasarkan gambaran klinis pada pasien diatas maka diagnosis sarkoma Kaposi juga dapat disingkirkan.

Penanganan granuloma piogenik dapat dilakukan dengan kuretase dan elektrokauterisasi, bedah eksisi, laser, cryotheraphy, schlerotheraphy, ${ }^{2,5,9,10}$ penggunaan laser pulsed-dye untuk kasus pediatrik, ${ }^{5}$ atau dapat digunakan krim imiquimod sebagai agen imunomodulator. ${ }^{9,11}$ Penatalaksanaan pada pasien ini dilakukan secara kombinasi yaitu dengan shave excision kemudian dilanjutkan dengan elektrokauterisasi. Pemilihan penanganan ini dimungkinkan karena tersedia dan dapat dilakukan pada lokasi lesi yang ada. Pengobatan dengan antibiotik sistemik siprofloksasin 2 x $500 \mathrm{mg}$ selama lima hari dan salap asam fusidat secara topikal tiga kali oles dalam sehari untuk mencegah terjadinya infeksi akibat penanganan yang dilakukan. Penanganan ini memberikan hasil yang memuaskan dimana granuloma menghilang dan luka setelah tindakan sembuh tanpa terjadi infeksi.

Prognosis pada pasien ini baik, walaupun terdapat kecenderungan untuk berulang (kekambuhan). ${ }^{5}$ Untuk mencegah terjadinya hal tersebut maka perlu menghindari faktorfaktor predisposisi. ${ }^{4,5}$ Bila disebabkan oleh obat kontrasepsi oral atau retinoid, maka pemakaian obat-obat tersebut harus dihentikan. Bila disebabkan oleh karena trauma, maka perlu menghindari trauma. Pada kasus ini perlu diingatkan untuk menghindari faktorfaktor predisposisi, terutama trauma minor yakni kebiasaan menggaruk telinga saat merasa bersalah ataupun canggung agar tidak terjadi rekurensi.

\section{KESIMPULAN}

Telah dilaporkan satu kasus granuloma piogenik multipel pada seorang laki-laki dewasa berumur 27 tahun, dengan faktor predisposisi kemungkinan trauma minor akibat kebiasaan menggaruk. Diagnosis ditegakkan berdasarkan anamnesis timbulnya benjolanbenjolan di bagian belakang telinga kiri yang mudah berdarah, tidak nyeri dan tidak gatal, adanya riwayat kebiasaan menggaruk telinga apabila merasa bersalah atau canggung, dan pada pemeriksaan fisik tampak papul eritem sebanyak enam buah berdiameter $0,2-0,5$ $\mathrm{cm}$, bertangkai, permukaan licin, konsistensi kenyal, dan mudah berdarah, serta pemeriksaan histopatologik menunjukkan gambaran granuloma piogenik. Penatalaksanaan dengan shave excision yang dilanjutkan dengan elektrokauterisasi memberikan hasil yang memuaskan.

\section{DAFTAR PUSTAKA}

1. Calonje E, Jones EW. Vascular tumors: tumors and tumor-like conditions of blood vessels and lymphatics. Dalam: Elder DE, editor. Lever's histopathology of the skin. Edisi ke-9. Philadelphia: Lippincott Williams \& Wilkins, 2005; p.1020-3.

2. Miller T, Frieden IJ. Vascular tumors. Dalam: Wolf K, Goldsmith LA, Katz SI, Gilchrest BA, Paller AS, Leffell DJ, editor. Fitzpatrick's dermatology in general medicine. Edisi ke-7. New York: McGraw Hill, 2008; p.1164-72.

3. Calonje E, Mackie RM. Soft tissue tumors and tumor-like conditions. Dalam: Burns $\mathrm{T}$, Breathnach S, Cox N, Griffiths C, editor. Rook's textbook of dermatology. Edisi ke-7. Massachusetts: Blackwell Publishing, 2004; p.53.1-47.

4. Pierson JC, Tam CC. Pyogenic granuloma (lobular capillary hemangioma) [homepage on the Internet]. Nodate [cited 2006 Oct 20]. Available from: URL: http://emedicine.medscape.com/article/1084701.

5. North PE, Hull C, Kincannon J. Vascular neoplasms and neoplastic-like proliferations. Dalam: Bolognia JL, Jorizzo J, Rapini RP, dkk., editor. Dermatology. 
126 Jurnal Biomedik, Volume 2, Nomor 2, Juli 2010, hlm. 121-126

Edisi ke-1. Edinburg: Mosby, 2005; p.1817-41.

6. James WD, Berger TG, Elston DM. Dermal and subcutaneous tumors. Dalam: Andrew's diseases of the skin. Edisi ke-10. Philadelphia: Elsevier, 2006; p.581-632.

7. Lichenstein R. Granuloma, annulare and pyogenic. J emedicine [serial on the Internet]. 2008 [cited 2009 Apr 27]. Available from: URL:http://www.emedicine.medscape.com/article.

8. McKee P, Calonje E, Granter SR. Lobular capillary hemangioma. Dalam: Pathology of the skin with clinical correlations. Edisi ke-3. Philadelphia: Elsevier, 2005; p.1815-7.

9. Tritton SM, Smith S, Wong LC, Zagarella S, Fischer G. Pyogenic granuloma in ten children treated with topical imiquimod. Pediatric dermatology. 2009;26(3):269-72.

10. Scheinfeld NS. Pyogenic granuloma. Skinmed: Dermatology for the clinician. 2008;7:37-9.

11. Ezzell TI, Fromowitz JS, Ramos-Caro FA. Recurrent pyogenic granuloma treated with topical imiquimod. J Am Acad Dermatol. 2006;54(5):S244-5. 